\title{
Entre a torre de marfim e o pelourinho
}

Simone Rossinetti Rufinoni

RESUMO: $\mathrm{O}$ artigo analisa - por meio de poemas em prosa do poeta Cruz e Sousa - as contradições entre o ideário simbolista e a constatação da realidade de um país escravocrata. $\mathrm{O}$ espaço da torre de marfim remete à singularidade do poeta eleito, enquanto que as teorias da inferioridade racial o condenam à barbárie e à exclusão. Estrutura, imagens e vozes apreendem tais conflitos, por meio dos quais se pode entrever a situação do homem de letras negro no Brasil do século XIX.

PALAVRAS-CHAVE: Cruz e Sousa, Simbolismo, poema em prosa, literatura e escravidão

ABSTRACT: The article analyzes - through prose poems by Cruz e Sousa - the contradictions between the symbolist ideals and the reality of a slaveholding country. The ivory tower space refers to the singularities of the elected poet, while the theories of racial inferiority condemn him to barbarity and social exclusion. Structure, images and voices capture these conflicts through which one can glimpse the black writer situation in nineteenth-century Brazil.

KEYWORDS: Cruz e Sousa, Symbolism, prose poem, literature and slavery 
Ele é o supercivilizado dos sentidos

Artista? Pode lá ser isso se tu és d'África...

Cruz e Sousa, "Emparedado"

O Simbolismo brasileiro sempre ocupou um lugar à margem no cenário das letras nacionais. Parte dessa tendência, a obra em prosa de João da Cruz e Sousa dificilmente encontra paralelo no modo singular com que perfila o encontro do grande autor ante o desafio de dar forma adequada ou possível aos assuntos intocados. O estilo carregado, híbrido, misto de ficção e confissão, desborda os limites do gênero poema em prosa na medida em que se presta à apreensão de certa faceta muito específica da vida social brasileira das últimas décadas do século XIX. A constelação de palavras de ordem simbolistas - o artista eleito, a teoria das correspondências, a primazia da imagem e da sonoridade, o viés decadentista dos temas, o traçado do poema em prosa à moda francesa etc. - choca-se com a matéria poética local que cada vez mais exige voz, abrindo espaço no panteão de sugestões canônicas. A matriz do assunto central, que clama por representação, encontra-se na vida do poeta negro, filho de escravos, educado pelo favor de brancos, cuja trajetória foi um rosário de humilhações e frustrações diante da carreira de homem de letras, que desejou sofregamente conquistar, que os novos tempos pareciam lhe franquear e lhe foi duramente negada. O novíssimo assunto, cuja forma não estava à mão, forçou caminho por dentro do molde simbolista que, talvez inapropriado, e ante a envergadura da empreitada, sofre alterações tremendas e resulta numa série de peças prolixas e retóricas, contudo fortes e surpreendentes no modo como o dialogismo encenado capta as forças históricas diante do tabu da situação e da condição humana do negro. Assim, a forma adotada parece acolher, devido ao gênero maleável, e se transfigurar, diante das tensões inerentes à natureza agônica do assunto, o lugar e a condição do homem negro, especificamente o de letras, na passagem do trabalho compulsório para o trabalho livre.

As vicissitudes do intelectual negro não foram, porém, assunto propositalmente escolhido, nem facilmente alcançado; parece que a experiência forçou espaço entre os lugares-comuns simbolistas exigindo presença, mesmo que à custa do ideal de inserção social expresso no exemplo flagrante dos poemas de circunstância do início de sua obra 
e, de modo diluído e intermitente, em quase toda a sua produção. ${ }^{1}$ Basta lembrar a prosa das Histórias simples, datadas de 1887 , cujo ponto de vista é o do branco aristocrata, cioso da preservação da família contra a influência perniciosa do caráter dos escravos.

O olhar atento pode acompanhar o escalonamento das imagens que, na lírica e na prosa, dão a ver marcas da escravidão, como a violência subterrânea ganha densidade imagética, como o regime da sugestão, premido pela vida bruta, delineia símbolos ou alegorias com maior ambição interpretativa, configurando o ponto de vista que, contraditório e revelador, será a tônica central de sua obra madura. Nesse percurso, mais palpável em sua prosa, ganha força a oscilação desmesurada entre o alto e o baixo, o Simbolismo e o cativeiro, a arte pura e a realidade desprezível. Tamanho descompasso pôde ser acolhido pela natureza híbrida e, de certo modo impura, do gênero poema em prosa; forma limítrofe, aberta a experimentações, afeita ao lirismo e à narratividade, descomprometida com as grandes sínteses, mais apartada da tendência ao sublime da lírica, e mais sujeita, portanto, à vertigem que não teme o fracasso estético. Sob esse prisma, a estrutura é o largo campo que acolhe conflitos, espaço do texto que produz conhecimento menos pelo alcance da síntese lapidar que pela urgência em desvelar a impureza da arte e da vida. Tal imperativo do risco prestou-se à encenação do conflito entre o ideal e a realidade posto nos termos específicos da oposição entre o artista simbolista, o eleito dos sentidos, e o homem negro em um país de escravidão recente.

O livro póstumo, Evocações, de 1898, talvez seja sua obra em prosa mais característica. Ao contrário de Missal, livro de estreia simbolista, cujas peças são mais orgânicas e afeitas ao molde importado, nessa obra tardia é notável o modo como a forma afina-se à dinâmica de sua trajetória e ponto de vista traduzidos por uma prosa em alta tensão, cuja liberdade revela forte caráter experimental. Característicos desse movimento oscilatório são o primeiro dos poemas, "Iniciado", e o último, "Emparedado". Entre eles que, como um pórtico, abrem e fecham o livro, testemunhando o ponto de virada ideológico, de cuja latência dá conta a inflexão enunciativa que lhes foi necessária, está o inquietante "Asco e dor". ${ }^{2} \mathrm{O}$ percurso que acompanhe tais modulações evidenciará

1. A respeito da relação da poesia de Cruz e Sousa com as condições de produção da época, ver: RABELlo, Ivone Daré. Um canto à margem: uma leitura da poética de Cruz e Sousa. São Paulo: Nankin/ Edusp, 2006.

2. Nesse percurso, como obra-prima de síntese, cristalização estético-histórica de seu périplo, figura a beleza incomum de "Dor negra", poema que não será analisado neste ensaio. 
o jogo de vozes e dicções que imprimem à sua prosa caráter ambíguo, de descoberta e inadequação, novidade e excesso.

Centrado na crença do ideal da arte, o núcleo temático do poema em prosa "Iniciado", de Evocações, ecoa o poema "O Assinalado", de Últimos sonetos, — “Tu és o louco da imortal loucura/ o louco da loucura mais suprema/ A Terra é sempre a tua negra algema,/ Prende-te nela a extrema Desventura// [...] Tu és o poeta, o grande assinalado/ Que povoas o mundo despovoado/ De belezas eternas, pouco a pouco..." - ao recair sobre a noção de assinalado como o "Vidente Ideal" ou "louco da imortal loucura", aquele capaz de transmudar o vulgar em bela forma. Nesse sentido, apesar das agruras que o aprisionam ao mundo, o eu revela-se capaz de lhe fazer frente por intermédio do caráter, de certo modo, purificador da arte.

Contudo, em face da história local, o poeta é identificado também e perversamente por outro tipo de "marca": é assinalado pela sua cor. Homem negro de letras num país recentemente egresso do sistema escravista, cuja ideologia do progresso compreendia os postulados científicos acerca da inequívoca inferioridade natural do negro ou mestiço, os traços da opressão se fazem ver principalmente em sua prosa, num contínuo diálogo entre ideologia e contraideologia. Da aura à mácula, da insígnia do ser de exceção à marca infame, índice do cativeiro.

Contrapostos, os poemas que compõem Evocações, qual peças de um mecanismo maior em cujos meandros a práxis ressoa, testemunham o paradoxo em que se vê enredado o poeta: por um lado, "assinalado" alude à natureza do sujeito eleito, tão cara ao ideário simbolista; por outro, a notação distintiva deve-se à filiação à chamada raça fraca, de onde advém o estigma da inferioridade articulado à animalidade e ao barbarismo inerentes à fisiologia do negro, de acordo com a ciência do período. ${ }^{3}$

A oscilação de sentido dada ao traço diferenciador torna-se obsessão em sua obra, tomando configurações poéticas diversas em torno da oscilação entre o alto - a poesia simbolista, a arte pura - e o baixo - o trabalho, a escravidão, a barbárie. O diálogo entre esses dois polos pede a investigação acerca dos motivos históricos que jazem sob a escolha de significações tão díspares. Os antagonismos do mundo real põem o par arte/vida em constante processo de busca por uma expressão adequada. Participa desse processo a

3. Cf. schwarcz, Lilia Moritz. O espetáculo das raças. Cientistas, instituições sociais e questão racial no Brasil - 1870-1930. São Paulo: Companhia das Letras, 1993, e SKIDmore, Thomas E. Preto no branco: raça e nacionalidade no pensamento brasileiro. Rio de Janeiro: Paz e Terra, 1989. 
opção pelo gênero - poesia ou poema em prosa - uma vez que a dificuldade do tema exigirá expressão de molde a dar conta da gravidade do conflito abordado. Desse modo, a forma manifesta a apreensão em profundidade de certo conteúdo histórico latente, cuja sedimentação, estetizada pela prosa simbolista de um autor negro, traz especificidades.

Não há síntese possível entre as duas esferas e o sujeito, incapaz de dar uma resposta decisiva à condição de classe legitimada por bases científicas, faz da prosa poética espaço de elaboração desse drama, enovelando-se entre o reconhecimento de si como o "iluminado" e a incontornável situação de ver-se como raça fadada ao atraso. As vozes que travam esse duelo comparecem em sua obra sob formas diversas; a fatura dissonante se valerá de imagens do mal inscrito na história, tecendo painel onde a violência, a exclusão e a morte se fazem texto.

Em alguns de seus poemas, o sujeito depara-se com a alteridade negra que se desvenda o outro de si mesmo; é parte de sua constituição física, mas se desconhece diante da iminência de suas faculdades intelectuais. Para o negro homem de letras no Brasil da época, o reconhecimento de si e de sua obra passa pela difícil inserção social, enfrentamento exacerbado quando posto sob a óptica da crença no artista como ser supremo, "homem de exceção". A altura em que se posta a concepção da arte cara aos simbolistas terá de se haver com a concretude do chão histórico. É, sobretudo, na complexidade da prosa poética do simbolista negro, que se pode observar a distância que medeia o ideal e a realidade consubstanciados em oscilações angustiantes, quer seja nas imagens que petrificam o gesto da perplexidade, na mistura de vozes ou no cunho satânico da linguagem.

O longo e retórico poema em prosa, "Iniciado", persegue a descrição do poeta como ser fadado a decifrar os signos do mundo, homem idealmente escolhido para transformar a vida em arte. A noção de gênio criador presente no poema remete à religiosidade da arte e à excepcionalidade do artista. Aquele que possui o dom - percepção por si só idealizante - de transfigurar o mundo abjeto em arte, a dor em bela forma, talvez glosando Baudelaire: "Tu más donné ta boue et jén ai fait de l'or" - "Tu me deste tua lama e eu fiz dela ouro". No poema, duas vozes fazem-se ouvir: a que enuncia clama à outra para que abandone o mundo em nome da arte, para que opte pelo exílio como modo adequado de se situar no mundo. Aqui, todavia, o diálogo é aparente, mera retórica: o eu e o tu confundem-se na medida em que comungam das mesmas promessas.

Em pauta, a profissão de fé simbolista marcada pela alquimia da palavra poética cujo poder é o de transformar o vil em sublime. Nega-se a realidade como etapa para vertê-la, de sua posição intocável, em arte. Nesse sentido, o artista deve buscar a dor a fim de estetizá-la: 
Porém, se és vitalmente um homem, e trazes o cunho prodigioso da Arte, vem para a Dor, vive na chama da Dor, vencedor por senti-la, glorioso por conhecê-la e nobilitá-la. Tira da Dor a mais profunda e radiante serenidade e a solene harmonia profunda. Faze da Dor a bandeira real, orgulhosa constelada dos brasões soberanos da poderosa Águia Negra do Gênio e do Dragão cabalístico das Nevroses, para envolver-te grandiosamente na vida e amortalhar-te na Morte!

Vem para esta ensanguentada batalha, para esta guerra surda, absurda, selvagem, subterrânea e soturna da Dor dos Loucos Iluminados, dos Videntes Ideais que arrastam, além, pelos tempos, para os infinitos do incognoscível futuro, as púrpuras fascinadoras das suas glórias trágicas. ${ }^{4}$

A dor, grafada com maiúsculas à moda simbolista, parece referir-se à sensação quase abstrata, idealmente pensada como substrato para a criação. Necessário tê-la para produzir arte. Não ocorre a indagação acerca da natureza humana e histórica dessa dor; quais seriam as possíveis angústias, os conflitos humanos por trás da forma sublime? $\mathrm{O}$ artista, por sua vez, é o "Vidente Ideal" que, possuído da "Dor dos Loucos Iluminados", ostenta as insígnias da condição de escolhido.

Nesse poema, paira a aura da crença na arte e, portanto, na absoluta superioridade dessa expressão diante do mundo que lhe dá origem. Curiosamente, é como se a matéria poética fosse menos relevante que o invólucro que lhe dará legitimidade. Só quando transfigurada pela mão da arte, pela floresta de símbolos, é que a realidade passa a existir.

Se não tens Dor, vaga pelos desertos, corre pelos areais da Ilusão e pede às vermelhas campanhas abertas da Vida e clama e grita: quem me dá uma Dor, uma Dor para me iluminar! Que eu seja o transcendentalizado da Dor!

Vem para a Dor, que tu a elevas e purificas, porque tu não és mais que a corporificação do próprio Sonho, que vagueia, que oscila na luxúria da luz, através da Esperança e da Saudade...

4. CRUZ E sousA, João da. "Iniciado". In: Cruz e Sousa. Obra completa. Rio de Janeiro: Nova Aguilar, 1995, pp. 520-1. 
Contempla-se uma indeterminação histórica da dor humana aliada ao caráter positivo do criador e do trabalho estético. Ambos figuram como inatos e essenciais, quase se confundem com a natureza.

Se é certo que trazes em ti a principal essência, as expressivas raízes, a flama eterna, o nebuloso segredo dos Assinalados, um poder mágico, irresistível, a que não poderás fugir jamais, te arrastará, te arrojará, como visão legendária, profética, numa grande convulsão e estremecimento, para fora das frivolidades terrestres, para fora das impressões exteriores do Mundo, mergulhando-te soberanamente, para sempre! No fundo apocalíptico, solene, das Abstrações e do Isolamento...

O artista como ser de exceção deve dar vazão a seu destino e a fuga da sociedade também comparte dessa necessidade. A renúncia ao mundo condiciona a criação:

Para resistir aos perturbadores ululos do mundo fecha-te à chave astral com a alma, essa esfera celeste, dentro das muralhas de ouro do Castelo do Sonho, lá muito em cima, lá muito em cima, lá no alto da torre azul mais alta dentre as altas torres coroadas de estrelas.

Vai sereno, belo Iniciado! Vai sereno para esta prodigiosa complexidade de sentimentos, agora que abandonaste a franqueza rude das montanhas, além, longe, na solidão concentrativa, no silêncio banhado de impressionante, comunicativa e augusta poesia, da tua terra de selvas e bosques bíblicos! 5

Neste trecho, bem ao fim do poema, nota-se a ostensiva presença da "torre de marfim", lugar imaginário que, desde os românticos, abriga o poeta da exclusão a que a sociedade utilitarista - e, no caso brasileiro, escravista - o condenou. "Castelo do Sonho", "torre azul", "altas torres coroadas de estrelas" são imagens que aludem ao espaço preservado dos males do mundo, onde a solidão torna-se condição para se alçar às grandezas da forma. Apartado da vida, portanto mais próximo da verdadeira arte.

A torre, como espaço da arte nobre, pressupõe a renúncia. O percurso para alcançá-la pressupõe o sofrimento característico do ideal ascético. Cabe lembrar, a esse propósito, o famoso ensaio de Valéry sobre o Simbolismo:

5. Id., pp. 523-4. 
A renúncia, vocês sabem, está muito próxima da mortificação. Mortificar-se é procurar, de uma maneira dura, e mesmo dolorosa, edificar-se, construir-se, elevar-se até um estado que suspeitamos ser superior. O desejo dessa elevação, dessa "ascese", pronunciando-se no campo da arte, tornando-se uma condição de vida do verdadeiro artista e da produção das obras, esse é o fato totalmente novo e a característica profunda que se observa em todos os participantes autênticos desse Simbolismo ainda sem nome. ${ }^{6}$

Nota-se a tríade renúncia, mortificação, ascese em "Iniciado". Afirma Valéry que, diante da difícil tarefa de identificar uma síntese estética nos poetas simbolistas, os une certa ética caracterizada pelo espírito de negação. ${ }^{7}$ Em face do ideal da arte cujo lócus específico é a torre de marfim, seria necessário ressaltar no que incide a dialética da negação tão própria a esse movimento. A objeção de Gide sobre a "falta de curiosidade acerca da vida", dos simbolistas, pode ser reinterpretada; sob novo enfoque, o desinteresse detectado figura como rejeição ao crescente utilitarismo da sociedade burguesa. ${ }^{8}$ Nesse sentido, o afastamento da vida em nome da arte, implica, dialeticamente, antes contato que recusa. Trata-se de salvaguardar o espaço da criação como esfera autônoma, por meio da qual é possível, sem se render à lógica que preside o mundo hostil, representá -lo. ${ }^{9}$ Por caminhos transversos, o idealismo art pour l'art floresce no terreno da atitude crítica. No contexto local, porém, o imperativo da "arte pela arte" - endossado por parnasianos e simbolistas - assume comumente caráter de ornamento. Sobretudo a lírica parnasiana, porta-voz dos valores da belle époque carioca, desveste o esteticismo do possível cunho antiutilitarista e o faz objeto de consumo da elite. ${ }^{10}$

Tal afastamento ideal dos males do mundo, contudo, não passará de quimera. A postura idealista desse primeiro poema cederá espaço a outras percepções menos positivadas, cada vez mais imersas na lama da vida, impedindo que o ouro da arte permaneça puro.

6. VAlÉRY, Paul. Variedades. São Paulo: Iluminuras, 1991, p. 68.

7. Segundo a formulação de Valéry: "A Estética os dividia; a Ética os unia”, Id.

8. WILson, Edmund. O Castelo de Axel. Estudo sobre a literatura imaginativa de 1870 a 1930. São Paulo: Cultrix, 1993, pp. 182-8.

9. Peter Burger considera o esteticismo etapa necessária à negação da autonomia da arte empreendida pelas vanguardas do início do século. Teoria da vanguarda. Lisboa: Vega, 1993.

10. Cf. NEEDELL, Jeffrey D. Belle époque tropical: sociedade e cultura de elite no Rio de Janeiro na virada do século. São Paulo: Companhia das Letras, 1993, p. 235. 
O poema em prosa "Asco e Dor" expressa a emergência do real degradado face à aristocracia da arte. ${ }^{11} \mathrm{~A}$ alteração da dicção enunciativa estabelece forte contraste com "Iniciado". Agora, a contrapelo do movimento de renúncia, o sujeito é obrigado a participar, uma vez que não pode permanecer imune às marcas gritantes e dilaceradoras do seu tempo que incidirão, inclusive, sobre a formação de sua subjetividade. Rompendo a crosta da mortificação com vistas à arte elevada, a história local exige resposta. Pelo viés muito particular da condição de poeta negro num país escravista é que se farão ouvir as vozes da vida social. $\mathrm{O}$ artista assinalado pertence, pois, paradoxal e irremediavelmente, à turba desumanizada dos negros, índice de barbárie. O espaço do ideal revela-se maculado pela emergência do mundo.

Assim é que, com "Asco e Dor", incidirá, sobre o dado genérico presente no poema "Iniciado", certa correção histórica. O narrador depara-se, em pleno espaço público, com uma cena que lhe figura hedionda: um grupo de carnavalescos dança freneticamente ao som de ritmos selvagens. $\mathrm{O}$ som associado à bestialidade refere-se ao carnaval, festa popular criticada pela elite branca. $\mathrm{O}$ evento entrevisto causa-lhe náusea; sente-se, ainda assim, atraído pelo estranho espetáculo. Tomado de asco, percebe-se quase hipnotizado diante do "desprezível bando" embrutecido que passa a representar, na confusão de desumanização, selvageria e flagrante alienação, uma imagem infernal prestes a dar especificidade histórica à dor indeterminada de "Iniciado".

Diante da turba ensandecida, o sujeito sente-se desconfortável:

E enquanto a multidão, vesga, atordoada, tonta, azoinada de calor, de rumos de carnaval e de poeira, aplaudia com gritos e zumbaias delirantes, ensurdecedoras, aquela turba vil, incaracterística, a minhalma sentia-se como que pendida de um cadafalso que a estrangulava, acorrentada a um asco mortal, a uma dor tremenda que não tinha linhas de unidade, de conjunto e de entendimento com as outras dores; dor ingenitamente original, que não participava, em nenhuma das suas fibras, em nenhuma das suas interpretações sensacionais, das outras dores do mundo! Dor legitimamente outra, que não tinha limites no limite da dor comum; dor que me parecia cobrir o céu de luto, enegrecer

11. O poema "Noctambulismo", de Missal, prenuncia "Asco e dor". Entretanto naquele, mais breve e genérico, o conflito reduz-se à sensibilidade do eu ofendida pela alegria do carnaval. Não comparece o conflito histórico; não há menção aos negros, consequentemente inexistem questionamentos identitários. João da Cruz e Sousa, op. cit., pp 468-9. 
tudo, aumentando-me o asco de tal sorte que o ar, os horizontes enublados, as árvores, as pedras das ruas, as paredes dos edifícios, a multidão que burburinhava, tudo me parecia estar possuído do mesmo asco e da mesma dor. Dor sem raízes conhecidas, sem ritmos definidos, sem origens encontradas nem na vida, nem na morte, fora das correntes eternas, das correlações das esferas, das circunvoluções do pensamento!.... ${ }^{12}$

Se em "Iniciado", o eu aborda a dor de modo genérico, a fim de acusar sua natureza desconhecida e exacerbá-la, aqui não se trata mais da abstração do sofrimento humano universal. As raízes da dor que tanto o tortura estão na história: a multidão é composta por negros e aquele que a observa traz em seu corpo os traços da barbárie. Vale notar que se, em "Asco e Dor", o poeta emprega o qualificativo "incaracterística”, a indefinição, aqui, refere-se, antes à dificuldade de compreensão e enunciação do conflito, que à universalidade do significado. ${ }^{13} \mathrm{~A}$ alteridade desprezível e hedionda é, numa breve passagem, explicitada: são os negros.

Dor e asco dessa esdrúxula, absurda turba que além, sob a tarde, uivava, desprezivelmente ridícula, na infrene mascarada, com os seus ínfimos vultos sinistros transfigurados em crocodilos, em serpentes, em sapos, em morcegos, em monstros bifrontes, todos, todos da mesma origem tenebrosa donde eu vim, negros, sob a lua selvagem e sonolenta dos desertos, no seio torcido das areias desoladas... ${ }^{14}$

A estrutura paratática absorve a dinâmica da dança e do desvario, como que emulando a hipnose alienante que os vitima.

A alma está, pois, "como que pendida de um cadafalso que a estrangulava" dada sua filiação:

Dor e asco dessa salsugem de raça entre as salsugens das outras raças. Dor e asco dessa raça da noite, noturnamente amortalhada, donde eu vim através do mistério da célula,

12. Id. "Asco e dor", op. cit., pp. 571-5.

13. A esse respeito, vale lembrar o poema em prosa "Dor negra”, também de Evocações. Neste, o aspecto incaracterístico da dor também não se relaciona à natureza universal; ao contrário, diz respeito à extrema dificuldade em representá-la.

14. Grifo meu. 
longinquamente, jogado para a vida na consciência geradora do óvulo, como um segredo ou uma relíquia de bárbaros escondida numa furna ou num subterrâneo, entre florestas virgens, nas margens de um rio funesto...

Ouve-se a voz da ideologia que, impregnada pelas teorias das raças inatas, condenava ao atraso os homens de tez escura. O sujeito é aquele que reconhece a inferioridade natural desse outro, mas sabe-se uma exceção, irremediavelmente atrelada a essa realidade. Renúncia e mortificação emergem por meio das especificidades da situação brasileira: quase como um refrão, o poema repete o par "asco e dor" - repulsa e sofrimento, desprezo e suplício - ambos referidos à situação concreta do negro na sociedade. $\mathrm{O}$ momento da festa carnavalesca auxilia a exploração dos sinais de inferioridade endossados pela ciência: animalidade, sujeira e selvageria.

Desdobrando o asco e a dor, o drama social, metaforicamente entrevisto, toma a forma de topos recorrente na obra do autor: a associação entre o riso e a dor. ${ }^{15}$ De modo diferenciado, a loucura acomete tanto o bando quanto o narrador. Para os foliões, a alegria desmesurada aproxima-se do transe presente nos rituais africanos tão temidos pela sociedade europeizada; para o sujeito, a perda da razão relaciona-se ao desnorteio ante a constatação de sua suposta natureza incivilizada. Por meio dos sentidos em convulsão patenteia-se a dor, agora prestes a historicizar-se.

A fenda entre idealismo e realidade é sentida pelo eu como ironia:

Asco e dor dessa ironia que para mim vinha, que para mim era, que só eu estava compreendendo e sentindo assim particular e exótica - ironia gerada nos lagos langues do Letes, fundida nas perpétuas chamas do Abstrato das esferas, ironia para mim só, só para mim descoberta nas camadas infinitas da Vida; ironia só para meu Orgulho, só para minha Ilusão humana, só para meu insatisfeito Ideal, ironia! Ironia! Ironia rindo às

15. Um bom exemplo dessa temática é o poema "Acrobata da dor", de Broquéis: "Gargalha, ri, num riso de tormenta,/ Como um palhaço, que desengonçado,/ Nervoso, ri, num riso absurdo, inflado/ De uma ironia e de uma dor violenta.// Da gargalhada atroz, sanguinolenta/ Agita os guizos, e convulsionado/ Salta, gavroche, salta clown, varado/ pelo estertor dessa agonia lenta...// Pedem-te bis e um bis não se despreza!/ Vamos! Retesa os músculos, retesa/ Nessas macabras piruetas d'aço...// E embora caias sobre o chão, fremente,/ Afogado em teu sangue estuoso e quente,/ Ri! Coração, tristíssimo palhaço", op. cit., p. 89. 
gargalhadas no fim da tarde pelas máscaras obtusas e pela boca parva da multidão que aplaudia truanescamente como o supremo truão eterno.

A dissonância localiza-se no abismo entre a percepção da torre de marfim almejada em confronto com a constatação da inumanidade biológica do homem negro; incide sobre o "orgulho", a "ilusão" e o "ideal", revelando a incompatibilidade entre reconhecimento pessoal, desejo de inserção e ideal artístico.

Em pleno espaço público, encena-se a ideologia da época. A cena de rua sofrerá os abalos da subjetividade que a captou. O drama do eu penetra o registro do fato, dando-lhe contornos deformadores, quase expressionistas. Nas mãos do poeta simbolista, o real, avesso ao naturalismo, sujeita-se ao tratamento antimimético: prevalece a imagem ambígua aliada ao lirismo e à narratividade, elementos por meio dos quais se persegue o espetáculo da subjetividade negra lançada no espaço reservado ao branco.

Mas o fatalismo científico do discurso naturalista também penetra essa prosa, destronando o ideal da arte abraçado pelo artista eleito. A natureza bárbara mede forças com o assinalado dos sentidos; a ponte entre as duas percepções é dada pela realidade chã da sociedade escravista brasileira. A abolição recente, o estigma da cor e do trabalho escravo maculando o fazer artístico. A ironia irrompe do paradoxo latente diante da natureza sublime do criador e grotesca do homem negro, ou, ainda, entremostra a fenda entre liberdade e natureza, dando a esta a força que a ciência lhe emprestou. Sem condições de fazer frente ao preconceito racial, o sujeito sente-o como fatalidade que o aterroriza tomando a configuração de um riso horrendo; a derrisão petrifica o ideal da arte e anuncia o drama de "Emparedado".

Como bem notou Anna Balakian, certa tonalidade fatalista presente em textos de orientação simbolista os aproxima do naturalismo. Ambos descreem, cada um à sua maneira, da providência; enquanto um se aferra às leis da sociedade e da ciência, o outro se influencia por forças misteriosas, externas à vontade do homem. ${ }^{16}$ Nesse sentido, as tendências aparentemente antagônicas se encontram em face da desconfiança diante do livre-arbítrio. Apesar da tão propalada subjetividade da expressão simbolista, o homem é também um joguete nas mãos do destino, daí o pessimismo, o desespero, a perplexidade. No caso do poeta brasileiro, a voga cientificista confunde-se com a ideologia da época, numa estratégia eficaz de legitimação da barbárie social, situação

16. Cf. balakian, Anna. O Simbolismo. São Paulo: Perspectiva, 1985, p. 106. 
que se impõe como matéria poética socialmente incontornável. A dinâmica dessas duas "fatalidades" - a força da ciência e a vertigem do destino - imprime seu movimento no texto configurando mais uma dobra da dialética entre Simbolismo e contexto local.

Imerso nas contradições de seu tempo, capazes de abalar a fortaleza da torre de marfim, o sujeito sente-se "como uma sombra irremediavelmente presa dentro de outra sombra" - na expressão significativa de "Asco e dor". A incompletude da imagem da "sombra" remete à subjetividade falhada, aquela que sequer se reconhece, que nem ao menos adquiriu representatividade histórica. A difícil imagem de si face à alteridade inumana está, por sua vez, presa dentro de "outra sombra", repisando a imagem do impasse que remete ao último texto do livro, o famoso poema em prosa "Emparedado".

"Emparedado" e "Iniciado" emolduram o livro Evocações. De iniciado a emparedado, do artista predestinado ao negro desumanizado instaura-se tenso diálogo em que comparecem as agruras do intelectual negro em uma sociedade marcada pela escravidão, pelo compadrio, pela recusa à arte simbolista, pela demonização do negro e pela fantasia do progresso atrelada ao projeto de branqueamento da nação.

"Emparedado" é longo poema em prosa que reúne os conflitos trabalhados pela prosa de Cruz e Sousa e fecha a obra Evocações. A escritura explora a liberdade e as potencialidades do gênero poema em prosa: é poema excessivamente longo, sua forma híbrida, misto de poesia, ensaio e confissão, e retórica presta-se à figuração do impasse da constituição da alteridade do sujeito histórico negro no Brasil.

A imagem do emparedamento, cuja referência literária remonta ao conto "O gato preto" de Poe, alude à petrificação e é emblemática da constatação da imanência sob o signo do impasse. O poema aborda a situação da arte e do artista diante das convenções, por meio de um prisma dialógico. Desamparado das ilusões de transcendência, a inflexão de "Iniciado" encontra aqui sua contraface.

$\mathrm{O}$ texto é cortado por imagens infernais. Estabelece, nesse sentido, contraste marcante com "Iniciado". Neste, vê-se a prevalência da luminosidade atrelada ao cenário do culto ao decorativo artificial à Huysmans, de par com certa notação exótica e genérica. Afim à notação positiva que prega o desprezo ao mundo pelo ideal, o poema é cumulado de signos da ordem da claridade, estabelecendo contraste flagrante com "Emparedado":

Pedrarias rubentes dos ocasos; Ângelus piedosos e concentrativos, a Milliet; Te Deum glorioso das madrugadas fulvas, através do deslumbramento paradisíaco, rumoroso e largo das florestas, quando a luz abre imaculadamente num som claro e metálico de 
trompa campestre - claro e fresco, por bizarra e medieval caçada de esveltos fidalgos; a verde viva e viçosa vegetação dos vergéis virgens...

Compare-se o trecho acima com a epígrafe de "Emparedado". Se as palavras que figuram no frontispício de um texto propõem o diálogo com o outro reverenciado ou notável, cabe registrar que, nesses dois poemas, talvez como uma espécie de reparação, a epígrafe é do próprio autor.

Assim como o início de "Iniciado", a dicção assumida é a da invocação; mas no novo cenário sugerido o refinamento fin de siècle dá lugar ao pessimismo:

Ah! Noite! feiticeira Noite! Ó Noite misericordiosa, coroada no trono das Constelações pela tiara de prata e diamantes do Luar, Tu, que ressuscitas dos sepulcros solenes do Passado tantas Esperanças, tantas Ilusões, tantas e tamanhas Saudades, ó Noite! Melancólica! Soturna! Voz triste, recordativamente triste, de tudo o que está morto, acabado, perdido nas correntes eternas dos abismos brumantes do Nada, ó Noite meditativa! Fecunda-me, penetra-me dos fluidos magnéticos do grande Sonho das tuas Solidões panteístas e assinaladas, dá-me as tuas brumas paradisíacas, dá-me os teus cismares de Monja, dá-me as tuas asas reveladoras, dá-me as tuas auréolas tenebrosas, a eloquência de ouro das tuas Estrelas, a profundidade misteriosa de teus sugestionadores fantasmas, todos os surdos soluços que rugem e rasgam o majestoso Mediterrâneo dos teus evocativos e pacificadores Silêncios! ${ }^{17}$

O sujeito conjura as forças da Noite que, impregnadas de negatividade fúnebre, destoam da plácida luminosidade anteriormente evocada. Nesse contraponto, a substituição da luz pela treva anuncia a derrocada das certezas, além de impor a conquista de uma imagética sintomaticamente negra que, não só nesse como em diversos momentos de sua obra, se organizará revitalizando criticamente a cor da pele escrava. Assim, o negrume contraposto à nitidez, ao mesmo tempo em que capta em profundidade a falácia das promessas civilizadoras, é índice, poeticamente formalizado, da consciência de crise do poeta.

"Emparedado" também se organiza em torno do tema do artista; neste caso, porém, o sujeito, já imerso no conflito histórico, perdeu a luta entre ideal e realidade.

17. CRUz E SOUsA, João da Cruz. “Emparedado”, op. cit., pp. 658-73. 
A dor indeterminada cedeu espaço à problemática bem datada do negro brasileiro premido entre as teorias racistas e a memória aviltante da servidão. $\mathrm{O}$ sujeito vê-se dilacerado diante das certezas da ciência confrontadas à natureza do vate, donde emerge uma incipiente crítica às teorias da inferioridade racial:

Nos países novos, nas terras ainda sem tipo étnico absolutamente definido, onde o sentimento d'Arte é silvícola, local, banalizado, deve ser estupendo o esforço, a batalha formidável de um temperamento fatalizado pelo sangue e que traz consigo, além da condição inviável do meio, a qualidade fisiológica de pertencer, de proceder de uma raça que a ditadora ciência d'hipóteses negou em absoluto para as funções do Entendimento e, principalmente, do entendimento artístico da palavra escrita.

Ante o concerto de vozes que o poema encerra, é significativa a adoção da terceira pessoa do singular, distanciamento que permitiria ver o impasse de modo imparcial. Mas o tom de serenidade será desmobilizado paulatinamente pelos dois parágrafos seguintes:

Deus meu! Por uma questão banal da química biológica do pigmento ficam alguns mais rebeldes e curiosos fósseis preocupados, a ruminar primitivas erudições, perdidos e atropelados pelas longas galerias submarinas de uma sabedoria infinita, esmagadora, irrevogável!

Mas, que importa tudo isso?! Qual é a cor da minha forma, do meu sentir? Qual é a cor da tempestade de dilacerações que me abala? Qual a dos meus sonhos e gritos? Qual a dos meus desejos e febre?

Note-se, no desdobramento de vozes, o matiz dialógico: da terceira pessoa (na citação anterior) passa-se, após a interjeição com marcas de pessoalidade em “Deus meu!", ao modo impessoal indignado, porém ainda indeterminado; no segundo parágrafo, chegase à primeira pessoa, à voz do poeta negro simbolista.

Característico do movimento oscilatório entre a adesão e a resistência às vozes hegemônicas, o sujeito desdobra-se entre eu e tu, expondo o impasse da alteridade do homem negro de letras distanciado da barbárie e, ao mesmo tempo, parte dela. O conflito revela marcas concretas da luta social: o desejo de adentrar o mundo dos brancos e obter lugar e reconhecimento social e a aversão aos ditames do discurso oficial que fazem da arte reprodução de lugares comuns e instrumento de demonização do negro. 
O movimento do poema reveza a percepção de si face ao outro com a percepção de si como o outro. A confluência de vozes, afim à dinâmica social, vai de encontro à síntese. $O$ processo de inacabamento frente à matéria social narrada comparte da inorganicidade e da fragmentação formais. Entretanto, não custa lembrar que a presença de vozes desarmônicas tornou o poema presa de leituras diversas: serviu àqueles que pretendiam ver na obra traços meramente biográficos, revelando o desejo de se tornar branco; ou, no polo oposto, expressava o anseio de Cruz e Sousa reconhecer-se como negro e postar-se ao lado dos abolicionistas. Tais leituras prescindem da complexa urdidura de vozes, de onde se divisa a problemática mais premente do poeta simbolista filho de escravos, um flagrante, em plena vigência das teses racistas, do lugar de fala do negro homem de letras ante os antagonismos de seu tempo.

Assim, o sujeito revela-se um duplo: é aquele que sofreu a exclusão e é aquele que observa o outro, num processo que contempla "o asco e a dor". Identifica a ideologia acachapante, investe contra ela, mas também reconhece em si traços desses ideais. Nesse trecho, ouve-se a voz da ciência da época:

O temperamento entortava muito para o lado da África: - era necessário fazê-lo endireitar inteiramente para o lado da Regra, até que o temperamento regulasse certo como um termômetro!

Ah! Incomparável espírito das estreitezas humanas, como és secularmente divino!

Por meio do dialogismo, descortina-se a apropriação da ciência que é mobilizada a fim de ser desconstruída: "o temperamento entortava muito para o lado da África". O uso do verbo "entortar" trai certa opção pelo jocoso que, deslocado, perde a conotação primeira e se faz ironia: o poeta alia dicção popular ao cientificismo, o que não condiz com o estilo empregado, revelando, pela apropriação inusitada, o contraste. No segundo parágrafo, põe-se a nu o ponto de vista crítico que une as duas falas, uma vez que a proposição não deixa dúvidas quanto à demolição do arcabouço científico. Essa voz que exclama também acusa a sutileza do matiz polifônico; a sentença final, a propósito da estreitez do espírito humano, assume a ordem superior cara aos juízos absolutos.

Entre a ideologia e a contraideologia não são claros os caminhos. A estrutura sofre as consequências das idas e vindas entre a adesão à ordem e a constatação da situação real e inescapável. A "torre de marfim" tornou-se quimera. O discurso cientificista é mobilizado por meio de uma estratégia que faz sua a ordem da traição: aproveita-se 
da voz dominante e a desconstrói. Em outros momentos, o enfrentamento se fará pela valorização às avessas dos signos de inferioridade, sobretudo aqueles que, constituintes da lógica perversa de legitimação da ordem escravista, propagam a animalização e a demonização naturais do negro. ${ }^{18}$

No fragmento abaixo, observe-se como o eu aposta no culto elevado da arte. $\mathrm{O}$ "tu" é o outro representante do senso comum, da convenção artística e defensor dos valores estabelecidos:

O que tu podes, só, é agarrar com frenesi ou com ódio a minha Obra dolorosa e solitária e lê-la e detestá-la e revirar-lhe as folhas, truncar-lhe as páginas, enodoar-lhe a castidade branca dos períodos, profanar-lhe o tabernáculo da linguagem, riscar, traçar, assinalar, cortar com dísticos estigmatizantes, com labéus obscenos, com golpes fundos de blasfêmia as violências da intensidade, dilacerar enfim toda a Obra, num ímpeto covarde de impotência ou de angústia.

Mas, para chegares a esse movimento apaixonado, dolorido, já eu antes terei, por certo - eu o sinto, eu o vejo! - te arremessado profundamente, abismantemente pelos cabelos a minha Obra e obrigado a tua atenção comatosa a acordar, a acender, a olfatar, a cheirar com febre, com delírio, com cio, cada adjetivo, cada verbo que eu faça chiar como um ferro em brasa no organismo da Ideia, cada vocábulo que eu tenha pensado e sentido com todas as fibras, que tenha vivido com os meus carinhos, dormido com os meus desejos, sonhado com os meus sonhos, representativos integrais, únicos, completos, perfeitos, de uma convulsão e aspiração supremas.

Não conseguindo impressionar-te, afetar-te a bossa intelectiva, quero ao menos sensacionar-te a pele, ciliciar-te, crucificar-te ao meu estilo, desnudando ao sol, pondo abertas e francas, todas as expressões, nuances e expansibilidades deste amargurado ser, tal como sou e sinto.

18. No contexto da sociedade escravista brasileira, o retrato do negro pautou-se por uma série de imagens demonizadas que articularam a ideia de inferioridade natural aos mitos cristãos legitimadores do racismo. Cruz e Sousa irá apropriar-se desses mitos e imagens corroendo-os ao inscrevê-los na história. Vale-se, para tanto, de uma reorientação de vários aspectos da semântica racista da época articulada à concepção simbolista do gênio criador. Cf. RUFINONI, Simone R. A forma negra da morte. Um estudo do satanismo no poema em prosa de Cruz e Sousa. Dissertação de mestrado. USP/ FFLCH, 1999. 
A arte simbolista comparece travestida pela significativa expressão "obra”. O caráter crítico e a complexa teia de dizeres não ocultam a ambição pela glória em uma sociedade em que homens de letras eram signatários de certo poder. A despeito da ambição pelo reconhecimento de seus pares, a arte como permanência adquire outra dimensão. Em sua obra, não se trata de exceção a preocupação com a literatura como possibilidade de inscrição do poeta negro no mundo: é tema largamente versado, insistentemente reposto. A ênfase na obra do artista traz como contraponto a realidade do trabalho bruto, braçal. As idas e vindas entre o "eu" e o "tu" entretecem falas de uma sociedade escravocrata que se moderniza de modo contraditório, dando a ver as complexas relações entre trabalho escravo e intelectual num contexto de desqualificação do trabalho livre.

As sociedades modernas, ancoradas na prerrogativa do trabalho livre, veem a obra intelectual com certa desconfiança, uma vez que sobre ela paira o estigma da improdutividade, afastando-a do respeito reservado às realizações manuais. O predomínio da utilidade aparta, cada vez mais, trabalho manual de trabalho intelectual, condenando o homem de letras a certa posição de marginalidade. ${ }^{19}$ Numa sociedade recém liberta da escravidão, porém, cuja vida social moldou-se pela convivência entre cativeiro e liberalismo, com as conhecidas relações de favor e compadrio que lhe são tributárias, a relação entre os dois modos de trabalho muda de sinal. Ao primeiro é reservado o desprezo, enquanto que o segundo é monopólio de poucos. Ante a atmosfera mental de país escravista, a complexidade e o sentido do trabalho do corpo e das mãos legitimam, para maior amplitude da discussão, a remissão aos critérios da Antiguidade.

De acordo com o mundo grego, a condição de escravo implicava inumanidade. No entanto, não se tratava de uma natureza inferior, mas de uma condição inferior; condenado à manutenção da vida, e consequentemente privado da humanidade livre, detentora da participação na pólis, estaria apartado da exigência única de cidadania. Assim é que a negação da humanidade do escravo relacionava-se à sua condição servil, de sujeição à necessidade. Qualquer alteração da condição de vida lhe permitiria a mudança de sua natureza e a manutenção da situação de submissão configurava desumanização. ${ }^{20}$

19. AREndt, Hannah. A condição humana. Rio de Janeiro: Forense Universitária, 2013, pp. 98-114.

20. Nesse aspecto, no caso brasileiro, em vista da impossibilidade histórica de desassociar o trabalho da animalidade, cabe considerar o quanto a inflexão suicida, que comparece em meio às muitas facetas que a morte assume na obra do poeta, ressoa o ato limite, único modo possível de restaurar a humanidade do negro ante a servidão e suas sequelas. 
A escravidão moderna, acrescida do peso da inferioridade como fato científico, não oferece nenhuma via possível de humanização. A obsessão pela obra que restará, obra do poeta fabricada pelas mãos e não pelo trabalho bruto do corpo, pode repor a dicotomia entre animal laborans e homo faber, dada sua inserção na questão da escravidão. A obra é memória, monumento erigido pelo homem que o salvaguarda contra o esquecimento; os escravos não produzem obra, mas trabalho. ${ }^{21} \mathrm{~A}$ obra de arte que fixa a memória dos homens é feita para e por homens livres. Para aquele que traz no corpo a lembrança do cativeiro, grande ambição seria a de realizar algo "inútil" que, contudo, contrariando o desdém pelo negro e pela arte simbolista, fixasse sua passagem no tempo, impondo o legado do sujeito pleno, acrescido da ousadia do caráter de artista assinalado.

O poeta negro livre trabalha com os signos de sua hora histórica: grava o estigma da cor e da violência do cativeiro, revelando o caráter falacioso da suposta mobilidade do mundo moderno. Daí a insistência na literatura como objeto que permanece, que sobreviverá à fugacidade, ao fincar suas raízes no tempo contra a corrosão e o fenecimento. Se a desconfiança jaz, por um lado, no caráter improdutivo do trabalho intelectual; por outro, só a obra de arte erige-se monumento durável o suficiente para fazer frente ao esquecimento, pois "é sempre na 'letra' morta que o 'espírito vivo' deve sobreviver". ${ }^{22}$ Homo faber, cujas mãos negras constroem o monumento à memória. ${ }^{23}$

Documento irrevocável da condição paradoxal que implica a existência do artista negro, a obra, enquanto monumento civilizatório, está sujeita à sabotagem. Os índi-

21. Segundo Hannah Arendt, a distinção entre "obra" e "trabalho" recai sobre "as mãos que operam e o corpo que trabalha", op. cit., p. 98. O trabalho, fruto do esforço do animal laborans, é destinado ao consumo; já o homo faber, fabricante do mundo, produz obra durável, objetos de uso que permanecem, op. cit., pp. 154-6.

22. Id., p. 211

23. "Assim, a durabilidade das obras de arte é de uma ordem superior àquela de que todas as coisas precisam para existir; elas podem alcançar a permanência através das eras. Nessa permanência, a estabilidade do artifício humano, que jamais pode ser absoluta por ele ser habitado e usado por mortais, adquire representação própria. Em nenhuma outra parte a mera durabilidade do mundo feito pelo homem aparece com tal pureza e claridade; em nenhuma outra parte, portanto, esse mundo-coisa [thing-world] se revela tão espetacularmente como morada não mortal para seres mortais. É como se a estabilidade mundana se tornasse transparente na permanência da arte, de sorte que certo pressentimento de imortalidade - não a imortalidade da alma ou da vida, mas de algo imortal alcançado por mãos mortais tornou-se tangivelmente presente para fulgurar e ser visto, soar e ser escutado, falar e ser lido", id. p. 210. 
ces que anunciam as possíveis investidas contra seu empenho em fugir à obscuridade assumem caráter gradativo e trabalham com sutilezas do discurso da época. Sujeita à profanação que implicaria "riscar", "traçar", "assinalar" os períodos de seu texto, a série culmina em "cortar [...] com golpes fundos de blasfêmia as violências da intensidade, dilacerar enfim toda a obra", complemento que acrescenta à série de verbos o peso de uma experiência que parece reviver o que há por trás dos impedimentos tão duramente pronunciados. No parágrafo seguinte, vale-se dos sentidos aguçados do artista contra o virtual ataque do mundo branco; tais atributos, tomados aqui como positivos, estão calcados na suposta natureza excessivamente sensitiva do negro, cujas raízes remontam à ferocidade natural, índice de selvageria. ${ }^{24}$ No trecho citado, os "golpes fundos" e a "dilaceração" que ameaçam a sua obra são expressões que acionam o conteúdo latente ao entremostrar parentesco com o castigo corporal. A hipótese fica mais clara em seguida: "Não conseguindo impressionar-te, afetar-te a bossa intelectiva, quero ao menos sensacionar-te a pele, ciliciar-te, crucificar-te ao meu estilo". Os verbos que aludem à depredação adquirem conotação cada vez mais próxima da violência que incide sobre a pele: "ciliciar", "crucificar" são amenizados pelo sujeito "meu estilo" - além disso, de modo dialético e reversível, a agressão atinge o outro incapaz de reconhecer a obra do negro. $\mathrm{O}$ jogo de negaceios dá a ver um sistema de camadas, onde a violência contra $\mathrm{o}$ texto do artista excluído, ao visar a obra que se faz memória do condenado à barbárie, desveste-se camada da violência concreta, castigo que se imprime na pele do cativo.

O quanto confluem texto e corpo, dada a articulação entre a palavra, na acepção de obra, e escravidão, pode ser aferido nesta passagem: "desnudando ao sol, pondo abertas e francas, todas as expressões, nuances e expansibilidades deste amargurado ser, tal como sou e sinto". O trânsito entre experiência estética e experiência física vem à tona; a imagem lembra o negro no pelourinho, "desnudado ao sol", cujas chagas, que pulsam sob as metáforas "expressões, nuances e expansibilidades", expostas são a prova pública da inumanidade do réu.

O pano de fundo do castigo corporal tinge outras cenas. Em seguida à vertigem profética de asserções, à previsão entusiasta do sucesso, emerge a constatação do

24. A passagem ecoa o poema em prosa "Capro", de Evocações, em que ocorre a apropriação da animalidade bárbara do negro articulada à teoria das correspondências e à voga do poeta assinalado, promovendo interessante releitura desses discursos. Cf. A forma negra da morte: um estudo do satanismo no poema em prosa de Cruz e Sousa, op. cit.

80 - RUFINONI, Simone. Entre a torre de marfim e o pelourinho 
impasse, que toma o lugar do idealismo. Longe da torre de marfim, mais próximo do cativeiro: mundo escravista cuja imagem-símbolo - espectro aviltante da tortura - é o pelourinho.

Tu és dos de Cam, maldito réprobo, anatemizado! Falas em Abstrações, em Formas, em Espiritualidades, em Requintes, em Sonhos! Como se tu fosses das raças de ouro e da aurora, se viesses dos arianos, depurado por todas as civilizações, célula por célula, tecido por tecido [...]

$\cdots$

Artista?! Loucura! Loucura! Pode lá ser isso se tu vens dessa longínqua região desolada, lá no fundo exótico dessa África sugestiva, gemente, Criação dolorosa e sanguinolenta de Satãs rebelados, dessa flagelada África, grotesca e triste, melancólica, gênese assombrosa dos gemidos, teoricamente fulminada pelo banzo mortal; dessa África dos Suplícios, sobre cuja cabeça nirvanizada pelo desprezo do mundo Deus arrojou toda a peste letal e tenebrosa das maldições eternas!

O "tu”, agora, é o outro de si mesmo. Uma voz interna, conhecedora dos meandros da ideologia, adverte esse outro interiorizado sobre sua ilusão. Multiplicam-se os motivos que impedem o sonho do artista supremo e o fazem emparedado: a natureza inferiorizada de sua raça e a filiação à África bárbara, de onde advém a reminiscência ao mito da maldição de Cam.

No desdobrar das vozes, o sujeito é acusado: "Tu és dos de Cam, maldito, réprobo, anatemizado!" - o parentesco com o mito promove a reflexão sobre a maldição, a injustiça e a culpa. Segundo o texto bíblico, a cor escura é o resultado da descendência de Cam, filho de Noé, aquele que foi amaldiçoado ao cometer o pecado de ver a nudez do patriarca. Este mito, articulado ao colonialismo mercantil e, depois, à ciência, serviu como justificativa atemporal para a servidão. ${ }^{25} \mathrm{O}$ sinal de excepcionalidade tornou-se anátema.

Mito e história travam um pacto contra o iniciado que se torna petrificado; à realidade daquele que pertence à barbárie associa-se o arquétipo cristão. $\mathrm{O}$ cruel dialogismo entre eu e tu expõe o nervo aberto do impasse da constituição da alteridade negra,

25. Perfazendo o que Alfredo Bosi chama de "mito de Cam racionalizado". Cf. вosı, Alfredo. "Sob o signo de Cam”. In: Dialética da colonização. São Paulo: Companhia das Letras, 1993, p. 271. 
em que comparece a difícil apreensão poética do conflito de toda uma classe. Essa voz lírica orquestra discursos disseminados que, ostensivos ou camuflados, mapeiam a complexidade da vida social.

A forte imagem do indivíduo emparedado, cujos sentidos ressoam o intertexto com o conto de Poe, já seria muito bem escolhida caso se limitasse ao liame entre o gato negro e a circunstância de absoluta impossibilidade. Mas outros desdobramentos potencializam a referência e a individualizam. A ação compreende o processo temporal que consiste no acúmulo paulatino de pedras sobre pedras, metáfora que consegue dar conta dos impedimentos longamente experienciados, da angústia dos ideais soterrados por uma sociedade conservadora e racista. Num nível mais profundo, os obstáculos reais dão lugar ao recalcamento das perdas acumuladas que atingem o paroxismo, explodindo em indignação e blasfêmia traduzidas por uma linguagem crispada e pelo redimensionamento local da imagem simbolista.

A pulsão à morte que o emparedamento implica comunica-se com a morte social do negro, como se lê no fecho do poema:

$[\ldots]$

Não! Não! Não! Não transporás os pórticos milenários das vastas edificações do Mundo, porque atrás de ti e adiante de ti não sei quantas gerações foram acumulando, acumulando pedra sobre pedra, pedra sobre pedra, que para aí estás agora o verdadeiro emparedado de uma raça.

Se caminhares para a direita baterás e esbarrarás ansioso, aflito, numa parede horrendamente incomensurável de Egoísmos e Preconceitos! Se caminhares para a esquerda, outra parede, de Ciências e Críticas, mais alta do que a primeira te mergulhará profundamente no espanto! Se caminhares para a frente, ainda nova parede, feita de Despeitos e Impotências, tremenda, de granito, broncamente se elevará ao alto! Se caminhares, enfim, para trás, ah! ainda, uma derradeira parede, fechando tudo, fechando tudo horrível! - parede de Imbecilidade e Ignorância, te deixará num frio espasmo de terror absoluto...

E, mais pedras, mais pedras se sobreporão às pedras acumuladas, mais pedras, mais pedras... Pedras destas odiosas, caricatas e fatigantes Civilizações e Sociedades... Mais pedras, mais pedras! E as estranhas paredes hão de subir, — longas, negras, terríficas! Hão de subir, subir, subir mudas, silenciosas, até às Estrelas, deixando-te para sempre perdidamente alucinado e emparedado dentro do teu Sonho... 
A estrutura de constantes repetições aqui se intensifica, denunciando a prolixidade do texto, aspecto, entre outros, apontado como prova da má qualidade de sua produção em prosa. Não obstante, pode-se considerar o quanto essa linguagem retórica se esforça por dar conta da revolta impotente ante a constatação do curso da história da opressão, dando vazão ao caráter coletivo da experiência pessoal. As pedras que circundam o sujeito perfazem um túmulo que o sepulta vivo, daí que a linguagem carregada é afim ao sofrimento atroz que implica a morte em vida, símile da experiência social do negro.

"Emparedado" pode ser compreendido como uma espécie de texto em que culminam diversos temas da prosa do autor. Elenco que compreende o fracasso dos ideais que comparecem em tantos de seus textos: expõe a profissão de fé do artista simbolista, oferta a dor como meio de redenção, elabora as formas do mal como estratégia de combate. A perda das ilusões, a natureza vil do negro, o passado da África darão ensejo a duas imagens da queda hauridas dos mitos bíblicos; estas, reelaboradas, dialogam e se opõem.

Assim, além da remissão a Cam, o poeta dispõe também do parentesco com o anjo caído, que permitirá urdir o grito de revolta pela revitalização dialética do drama do rebelado. Se esses dois mitos se assemelham — dadas as invariáveis estruturais: proibição, transgressão, culpa e danação - , enquanto o primeiro se prestou à justificação da exclusão, o outro foi, ao longo da história das artes, relido e ressignificado, tornando-se moderno símbolo de revolta. O teor blasfematório, indignado e crivado por imagens soturnas, assume esse caráter ao aludir ao poeta como um anjo maldito, cuja técnica polifônica permite fazê-lo uma espécie de traidor dos anteriormente cobiçados valores da elite. As outras camadas dessa complexa teia articulam esse satanismo à semântica demonizadora do negro e ao ideário em torno do escolhido, o "supercivilizado dos sentidos". Como resultado, o poema promove a vinculação do embate concreto à maldição bíblica: o arquétipo da queda primordial, ao mesmo tempo em que legitima a gênese do cativeiro, o enfrenta, por meio da prosa que se vale da imprecação satânica contra as ilegítimas bases da opressão.

A peculiar fatura - caudal prolixo e embriagante de vozes e símbolos - cunha, aos poucos, um espaço literário de tensões consubstanciadas pela figuração de um lugar de fala específico: o do visionário satânico, a uma só vez, eleito e excluído. A conquista desse lócus poético ancora-se na desconstrução e revalidação da semântica das formas do mal mítico e social. As nuances dessa apropriação, para além da irregularidade formal, permitem aferir como a literatura de Cruz e Sousa urdiu o vínculo entre o mal, tornado fonte de resistência, e o estatuto simbolista do gênio criador, promovendo 
curiosa confluência de sentido que diz muito da vida social brasileira sob o crivo do discurso indireto da imagem.

Por meio do confronto de vozes é possível traçar as linhas de força da difícil alteridade do negro no Brasil de fins do século XIx, imagem agravada pela especificidade desse homem de letras na periferia, premido entre a idealidade e o cativeiro. Cada vez mais distante da torre de marfim, a ascese dá-se sob a forma invertida do paradoxo: pelo avesso do discurso da época, formas do mal se tornam modos poeticamente eficazes de enfrentamento e representação.

Simone Rossinetti Rufinoni é professora de Literatura Brasileira na Universidade de São Paulo, autora de Favor e melancolia: estudo sobre A menina morta, de Cornélio Penna (Edusp/ Nankin, 2010). 